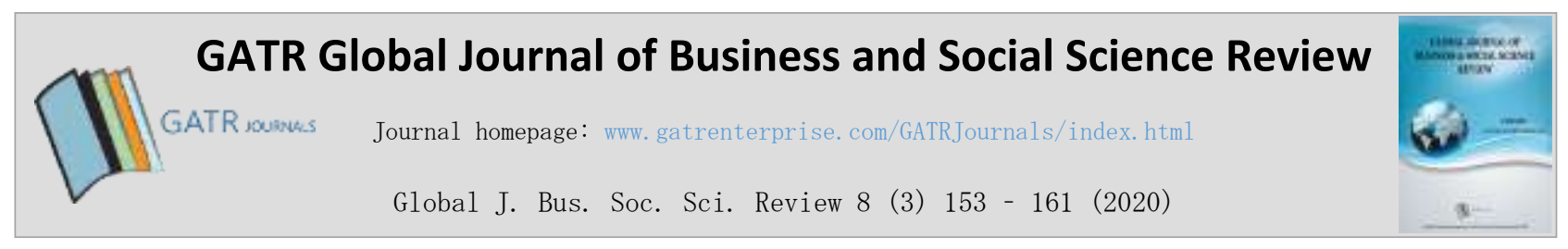

\title{
A Précis on Intellectual Property Rights: Challenges and Prospects for Nigeria's Economy
}

\author{
Olasunkanmi Olusogo OLAGUNJU \\ Centre for Economic Policy Analysis and Research, Faculty of Social Sciences, University of Lagos, Nigeria
}

\begin{abstract}
Objective - This research study examines the benefits and advantages associated with Intellectual Property Rights (IPRs) in Nigeria's ecosystem. It scrutinises the contributions of safety or security of heroic inventions and innovations to economic growth.

Methodology/Technique - With the adoption of institutional theory, this study examines the pertinent legal instruments, administration and challenges of IPRs in Nigeria. The paper is specifically built on content analysis, key informant interviews, and expert insights which are used to unearth the institutional framework for transforming IPRs into sustainable economic or financial assets.

Finding - Based on content validity of the research, it is concluded that IPRs can be transformed into sustainable economic wealth or tangible financial resources with the creation of institutional apparatus for mitigating theft, piracy or illegal transfer of IPRs in Nigeria as well as other developing nations. Consequently, some key policy suggestions necessary to secure IPRs for economic growth or optimal performance are espoused in this study.

Novelty - The paper makes findings relevant to how institutional weaknesses actually spearhead the growth of theft, piracy and illegal exchange or utilisation of intellectual resources of Nigeria.
\end{abstract}

Type of Paper: Review.

JEL Classification: O31, O43, K21, O1, O17

Keywords: Institution; Rights; Economy; Property; Security; Administration.

Reference to this paper should be made as follows: OLAGUNJU, O.O. (2020). A Precís on Intellectual Property Rights: Challenges and Prospects for Nigeria's Economy, Global J. Bus. Soc. Sci. Review, 8(3): 153 - 161. https://doi.org/10.35609/gjbssr.2020.8.3(2)

\section{Introduction}

Nigeria is fast turning into a subject of focus for the world, in light of the strategic importance of intellectual property to optimal performance across all sectors of the economy (Kholis, 2017; Azam, 2020). Despite the great inflow of revenue and business prospects from intellectual property security over the past decade, there are profound setbacks that impede the optimal performance of Nigeria's economy.

\footnotetext{
* Paper Info: Revised: June 16, 2020

Accepted: September 30, 2020

* Corresponding author: Olasunkanmi Olusogo OLAGUNJU

E-mail: olasunky004@yahoo.com

Affiliation: Centre for Economic Policy Analysis and Research, Faculty of Social Sciences, University of Lagos, Nigeria
} 
One such setback is the inability to explore the huge economic benefits embedded in viable protection of intellectual property rights - this has a huge prospect for inflow of development revenue, which can be used in government spending. The Nigerian government is yet to make any significant reforms to preserve domestic innovations and patents, which requires drastic policy revision.

A variety of studies from Umar \& Muhammad (2015) and Wusu (2013) examined how innovation in information technology has stimulated the request for security of intellectual inventions outside the territorial boundary of any nation. Most developing countries suffer bitterly from the scourges of unchecked intellectual property piracy or theft. However, there are diverse arguments stating that most copyrighted and patented works proceeding from some advanced countries represent merely the products of exploitation of traditional paraphernalia and mythologies of developing nations (Adewopo, 2013).

One area through which Nigeria can explore huge investment growth and optimal performance depends on the development of groundwork for safeguarding IPRs - it would culminate in increased growth and effectiveness in productive activities and sectors (Roisah, 2017). It is highly regrettable that after decades of independence, Nigeria is yet to make a vital reform to existing IP laws, which are largely outdated. Generally, intellectual property rights aim at ensuring and protecting the utilization of data and information that possess commercial and strategic worth, and these include copyright, trademarks, or patents.

Baten et. al. (2017) and Amparado and Miro (2020) argue that intellectual property rights actually deter imposters from deriving undue advantage from various innovations or inventions belonging to someone else and provide applicable remedies if the need arises. In most countries, IPRs are encoded in the statutory regulations of the country. Lemley (2015), Kholis (2017) and David (2007) imply that IP laws bestows inventors special rights to a range of intangible assets including discoveries, artistic works, literary works, inventions, symbols, and designs. However, IP laws in Nigeria are designed to remunerate originators of intellectual materials by forestalling charlatans from illegitimate or unauthorized utilization of patented works without prior approval and consent.

It is against this background that this study seeks to examine the contributions of intellectual property rights to inclusive growth in Nigeria. Based on the content review, key informant interviews, and expert insights, the study scrutinizes the institutional frameworks of administration, legal instruments, and enforcement of compliance on rules guiding the utilization of intellectual innovations and inventive materials and the viable security of IP rights within the ecosystem.

\section{Intellectual Property Rights and Theoretical Underpinnings}

Stanford Encyclopedia of Philosophy (2020) and (Roisah, 2017) view intellectual property as part of human assets and/or capital. Intellectual property denotes a set of inventions and innovations which gives an institution - public or private - a viably strategic value. Therefore, intellectual property also represents the materials, knowledge, information, inventions, or experiences which can be converted into tangible wealth. More importantly, the World Intellectual Property Organization (2020) defines intellectual property as a broad term for the set of intangible assets owned and legally secured by an institution from external use or implementation without consent.

Owing to its capacity to bestow productive institutions with reasonable or strategic rewards, defining intellectual property as an asset aims to afford it the same security rights as physical property. Gaining access to such defensive rights is very serious because it averts reproduction by possible competitors that may pose a severe threat to domestic industries or productive sectors. Put differently, Falvey et. al. (2006) and Amparado and Miro (2020) define intellectual property rights as a protective framework to safeguard vital discoveries by bestowing prosperous innovators transitory monopoly power over their inventions. The monopoly returns usually provide substantial benefits on venture in research and development, which are relatively large to compensate for the high share of research and development investment. 


\section{Institutional Frameworks on Intellectual Property Rights in Nigeria}

The importance of IPRs in stimulating economic growth in Nigeria cannot be understated. However, any institution that possesses statutory rights to intellectual property can obtain ample advantages from it in diverse ways (Ezekude, 2013; Moudio, 2013; Ahmadi et. al., 2010). This is possible where the institution uses intellectual property internally for its own processes to deliver efficient services to customers. More importantly, the benefits of intellectual property rights are actualized via several legal devices such as royalty rights. In more recent time, there exists extensive global standards for defining, protecting, and enforcing intellectual property rights, which consist of both multilateral treaty schemes and international organizations.

Nonetheless, there exists some variation in the implementation of intellectual property rights at a domestic or local level. Notably, these rights enable inventors or originators of patents, trademarks or copyrighted materials to exclusive value from their own intellectual works. More importantly, the legality of IPRs are defined in Article 27 of the Universal Declaration of Human Rights (UDHRs), which substantively offers adequate yields from the security or management of explorations resulting from authorship of scientific, literary or creative productions (WIPO, 2020; Kholis, 2017).

However, the pre-eminence of intellectual property rights was first recognized in the Paris Convention for the Protection of Industrial Property (1883) and the Bern Convention for the Protection of Literary and Artistic Works (1886). The World Intellectual Property Organization oversees these treaties. More specifically, statutory rights acquired recognition, especially in post-industrial age, where the manufacture and manipulation of goods has given way to the production and reproduction of knowledge and execution of innovation.

However, these rights are increasingly required by firms as a source of strategic benefit, as a mechanism for market security, and as a negotiation currency to forestall being "locked-out" from using technologies possessed by competitors. This development in utilization of these institutional and legal rights in Nigeria increases motivation to invent and equally apply the knowledge in production of lucrative outputs. This actually represents a policy question for productive or economic sectors with regard to whether intellectual property right can serve as a tool for enhancing technological innovation in Nigerian economy.

\section{Pertinent Intellectual Property Instruments in Nigeria}

As a class of assets in Nigeria's economic landscape, IPRs are often categorised into 4 diverse types including trademarks, patents, copyrights, and trade secrets. Copyrights are the most popular intellectual assets in Nigeria, for being a form of security and safety granted to the authors of diverse forms of original works (Amparado and Miro, 2020).

. A copyright secures a tangible form of expression which may include a book, work of art, music and/or video rather than the idea or subject matter itself. However, copyright protection has gained popularity in Nigeria and is currently applicable to any original work of authorships from the time that it is created in a tangible form.

Trademarks represent those expression, names, symbolic materials, or any combination which are utilized or proposed for utilization in commerce or any economic activities to detect and differentiate the goods of one manufacturer or seller from goods manufactured or sold by others (Baten et. al., 2017). Even though it is not as vigorous as the security system for copyrights, a trademark provides some international safety for domestically registered innovations.

Patents are the most valuable, exorbitant, and elusive IPRs to obtain. A patent implies the grant of a property right to the inventor thereby giving the owners legal rights to exclude others from making, using, offering for sale, selling, or importing the invention. However, patentable items actually include objects or processes including new technology or business inventions, but excludes more abstract items such as websites or ideas. Adequate documentation from the applicant together with verification of originality by the relevant agencies are required before the grant can occur, and is then typically valid for 20 years from its

Global J. Bus. Soc. Sci. Review 8 (3) 153 - 161 (2020) 
inception. As soon as it is received, a patent owner is statutorily authorized to distribute franchise or issue licenses to others for usage of the invention or its design and may charge a fee for such usage.

Trade Secrets are a form of ideas or facts that are officially undisclosed by a business corporation. A trade secret denotes a unique form of intellectual property which does not have a distinct time horizon (Singla, 2008). However, an issue could remain simply secret while applying for a patent or it could remain closely guarded for the lifetime of the firm. A trade secret can be construed as commercial data that an organisation or group of individual uses or to which they possess exclusive rights. In order to be recognized or deemed a trade secret, the information must meet carefully specified requirements, it provides the owner with competitive or economic advantage, and is genuine and not obvious or levelheadedly safeguarded against a leak.

\section{The Legal Frameworks on Intellectual Property in Nigeria}

In this growing age of globalization, it should be noted that domestic or local legislation alone are not capable of protecting intellectual property rights outside the borders of any given country. To protect such rights at an international level, there is need for a supportive international protective regime (Lemley, 2015). This growing need has informed the emergence of various international instruments and conventions on intellectual property. However, for the purpose of this study, legislation affecting intellectual property rights in Nigeria is delineated into international instruments as well as local legislation.

\section{The International Instruments}

Nigeria, like most countries, is a signatory to the universal conventions which set globally acceptable standards by which domestic legislation concerning intellectual property rights must attain to accord those rights at a global level (Nordfors et. al., 2003; Amparado and Miro, 2020). There exists some agreement on the trade-related aspects of IPRs which affirm the flexible opportunities available to member states seeking to protect their inventions. Furthermore, there are several international instruments including the Paris Convention for the safety of industrial assets such as symbolic patents, industrial designs, or trademarks. This includes those conventions establishing the WIPO, Universal Copyrights Convention, and other Copyright Treaties, among others.

However, the legality and dependability of these international instruments are often challenged in some quarters. Under international law, a treaty once consented to by a state becomes authoritative on such state to perform all the responsibilities arising under such treaty. Therefore, the United Nation's Conventions on Intellectual Property and African Regional Intellectual Property Organization's treaties have been incorporated into Nigeria's domestic law.

These are statutes with international support containing the bills of rights. The position of international treaties vis-à-vis national execution of intellectual property rights is stipulated to indicate that any international treaties entered into by Nigerian government cannot be enforceable or operational if not legislated by the National Assembly. However, the LFN 1999 further stipulates that:

"where the international treaty is enacted into law by the National Assembly and incorporated into municipal or domestic law, like the African Charter on Human and Peoples' Rights (Ratification and Enforcement) Act, it becomes binding and the courts must give effect to it like all other laws falling within the judicial powers of the courts."

More specifically, the 1999 Constitution of the FRN provides that:

"Before its enactment into law by the National Assembly, an international treaty has no such force of law as to make its provision justifiable in our courts." 
However, some International Non-Governmental Organizations such as the International Trade Marks Association, Anti-Counterfeiting Group, International Anti-Counterfeiting Coalition, Global Congress on Counterfeiting and Piracy, as well as the International Federation of Phonographic Industries among others have also played an important role (Singla, 2008; Okejiri, 2003; Rosiah, 2017). These organisations played extremely significant roles in the safety and advancement of IPRs across global ecosystem.

Being a foremost legal instrument for securing the rights of inventors, the International Trade Marks Association works to foster efficient trademark laws and policies worldwide and harmonize their implementation globally. The International Anti-Counterfeiting Coalition represents the world's largest nonprofit organization devoted solely to defending intellectual innovations and forestalling illegal reproduction.

The Global Congress on Counterfeiting and Piracy on the other hand has emerged as the paramount international platform for reinforcing viable strategies to mitigate the collective challenges inflicted by the universal quagmires of theft and piracy, and the International Federation of Phonographic Industries represents the institution that promotes the interests of these recording and filmmaking sectors worldwide.

\section{Local Legislation}

In Nigeria, there is a local legal regime for the protection of IPRs. The most pertinent local legislation influencing intellectual property in Nigeria is the "Constitution". This is the ultimate national legislation and consequently superior to all other laws in the country. Its provisions on any subject matter overrides the provision of any other laws on the same subject. However, intellectual property such as copyright, patent, industrial designs, trademarks and merchandize marks are items enshrined on the exclusive legislative list (Ayoola \& Chikwuendu, 2014). It is to be understood that the National Assembly has sole legislative power to enact, amend and repeal legislations pertaining to these areas. The National Assembly has sponsored a review of the Nigeria's intellectual property laws with a view to bringing those laws into conformity with universal standard in view of Nigeria's obligations under various international treaties.

In addition to the Constitution, intellectual property is regulated by 5 main local statutes including the Copyright Act, Patent and Designs Act, Trade Marks Act, Merchandise Marks Act, and Companies and Allied Matters Act. However, the Copyright Act regulates fictional, musical, artistic works, cinematograph films, and inventions whilst industrial designs are governed by the Patent and Designs Act (FGN, 2004). Similarly, trademarks are protected by the Trade Marks Act, while business names are protected by Part B of the Company and Allied Matters Act.

Other legislation that applies to intellectual property in Nigeria is the common law which takes care of certain aspects of intellectual property rights like passing off relating to unregistered trademarks, unfair competition and disclosure of trade secrets that are not provided for in any of the aforementioned statutes. There is also various subsidiary legislation made by the relevant authorities to exercise their constitutional powers as contained in those foregoing principal or enabling statutes.

It should be noted that these subsidiary statutes in relation to copyright are: the Copyright Order which extends protection to copyright works emanating from Nigeria as a signatory to the Universal Copyright Convention of 1952. The Copyright Order regulates and provides the procedure for the formation and functions of the societies, regulates video rental activities and sound recordings as well as cinematograph films.

On patents and designs, the Patents and Designs Order covers patent application or registration of a design; the Patent and Design Rules addresses the administration and procedure for the operation of the Patent and Designs Act. There is also the Trade Marks Regulations, which regulates application fees, registrations and other matters relating to the practice under the Trade Marks Act. The laws explained above represent the legal regime for securing intellectual property rights in Nigeria. There is therefore ample or security for the intellectual property rights invented by Nigeria nationals and foreigners in line with international treaties and conventions (FGN, 2004). 


\section{Administration of Intellectual Property Rights in Nigeria}

In order to ensure effective administration or co-ordination of activities relating to intellectual property, some regulatory institutions have been established to further strengthen the system in Nigeria. Amongst them is the Nigerian Copyright Commission founded by the 1988 Act as the key institution with the responsibility to regulate copyright matters in Nigeria (FGN, 2004). This Commission also regulates and oversees the control and operations of collective societies for various classes of copyright protected works. The Commission is currently set up as a government institution under the control and direction of the Federal Ministry of Justice.

Similarly, the Nigerian Intellectual Property Office also known as the Trademarks, Patents and Designs Registry regulates the management of industrial property in Nigeria. It was established for the management of trademarks, patents and designs applications in Nigeria. There is also the National Film and Video Censors Board established by Act No. 85 of 1993 as the official regulatory institution for the film and video industry in Nigeria. The Board censors, classifies and rates both films and video works produced in Nigeria, and foreign films and video works imported for the Nigerian market. The Board also licenses and registers all film and video outlets across Nigeria and keeps the records of the registered outlets while attending to other pertinent duties.

The National Office for Technology Acquisition and Promotion was created to nurture creative talents, identify scholars and designers, and create an enabling environment for inventors and creative works, among other things (NOTAP, 2013; Obiaya, 2013; Roisah, 2017). The Institution's core duties include to review/register agreements on technology transfer, the advancement of intellectual property, technology advice and support facilities. It currently seeks to assist local inventors in the process of upholding and exploiting inventions or innovations facilitated or sponsored by government funded research institutes and private organizations.

However, in complementing the role of these public institutions, some non-governmental bodies also play very decisive roles in the administration of intellectual property in Nigeria. These include the Copyrights Society of Nigeria, which is a non-profit organization of all owners of copyrights in musical works and sound recordings. It is a strong force in the fight against copyright infringement and other forms of piracy in Nigeria (Waziri, 2012; Pisacreta, et al. 2011). However, the legal status of other unregistered collecting societies and associations for musical works is currently uncertain in the light of recent litigation regarding the same. There is also the Reproduction Rights Society of Nigeria, which was authorized to function as a collecting society for reprographic rights in 2003, with finance support from the Reprographic Rights Organization of Norway.

The Intellectual Property Institute of Nigeria is a non-profit institution established for promoting the use of intellectual property or capital as tools for sustainable growth in social services, technology and the economy. The Institution also seeks to promote awareness and understanding of the use of intellectual property through activities including intellectual property studies, public advocacy, expert training and seminars, technical/institutional support, and consultative forums. The LFN 1999 vests exclusive jurisdiction in the Federal High Court to handle disputes relating to copyright, patent, trademarks and passing-off, industrial designs and merchandise marks. Further, the Registrar of Trademarks acts as the Tribunal to adjudicate over disputes and applications arising from the operation of the Trademarks Act.

The Registrar is statutorily empowered to hear and decide upon belligerent and non-belligerent applications including applications arising from trademark opposition proceedings. The Registrar may make, expunge or deter an entry into the trademark register on the application of an interested person. The Tribunal also adjudicates on appeals against the refusal of trademark applications by Trademark Examiners. The Trademarks Act also permits an applicant to submit request to the Federal High Court to exercise the constitutional powers of Tribunal for trademark abuse. In order to foster development and to actualise the Nation's vision, research is continuously undertaken in this space. 


\section{Challenges of Intellectual Property Rights in Nigeria}

It is undeniable that political as well as economic instabilities have conditioned some people or groups of people to engage in piracy or intellectual theft (Rana, 2016). In some local markets, particularly in Lagos State, thousands of people depend on the unfettered sale of second hand movie videos while some thrive on the unsolicited transfer of intellectual data (Waziri, 2012; Adebayo and Kolawole, 2013). When there is an economic problem as well as political disorder, the tendency of unrestrained piracy and intellectual theft will affect the commitment and optimal performance in various economic sectors. However, Nigeria has been denoted in recent times as an economically unviable nation due to its somewhat intractable economic and political instabilities. These problems have consequential effects on the protection of intellectual property rights by the appropriate institutions.

The problems pertaining to inadequate storage facilities in the country has affected efforts to ensure that every avenue for leakages in flow and usage of intellectual property is halted. Where there is a national database system for overseeing intellectual property security, there will be motivation for investors to grow the economy in Nigeria (Wusu, 2013; Adedeji, 2004; Obiaya, 2013). When inventions and innovations are well stored, it is more likely that performance and productivity may be enhanced among interested parties.

The incidence of poor governance among the political leaders in Nigeria has reinforced economic hardships that make criminal activities more lucrative. More specifically, some illicit traders at Alaba market in Lagos State are thriving on intellectual property theft because the government has failed to create viable alternatives for human survival (Adewopo, 2013; Roisah, 2017; Moudio, 2013). More often than not, some political representatives are accused of collecting bribes or illegal settlements from these intellectual property hijackers, contributing to the uncontrollable growth of theft and piracy of intellectual innovations in Nigeria's productive sectors.

Nigeria has historically lacked the necessary technological capability to protect intellectual property rights (Lemley, 2015). This has drastically reduced the growth of performance in some industrial sectors. Nigeria lacks a national database for electronically monitoring the distribution, transmission and exchange of intellectual materials thereby affecting the commitment of relevant stakeholders in investment in Nigeria's economy.

Nigeria is a country where the necessary infrastructures for protecting intellectual innovations are either in short supply or are virtually non-existence. Nigeria is one of the poorest countries in terms of its national database management system. This indicates that national management of intellectual property is low due to the inadequacy of data protection infrastructure.

\section{Conclusion and Prospects}

This paper concludes that intellectual property rights influences efficiency and performance in Nigeria. Furthermore, it concludes that satisfactory safety of intellectual property rights fosters job creation and improves profit prospection for small business operators (Rana, 2016; Roisah, 2017). However, the absence of proper storage facilities and a weak database management system negatively affect the safety of pertinent inventions. It is against this backdrop that this paper concludes that intellectual property rights contribute significantly to economic performance.

However, this paper also concludes that poor or weak leadership has an effect on the safeguard of national innovations in Nigeria (Ayoola \& Chikwuendu, 2014; Obiaya, 2013). This paper therefore recommends that maintenance mechanisms should be established so that intellectual capital can be used to stimulate unprecedented economic productivity. Consequently, the government, in collaboration with the relevant private bodies, should support the establishment of proper storage facilities to safely store new and old inventions and innovations.

Moreover, the interested parties through organised bodies should sponsor information technology specialists who will work assiduously in the coding and encryption of contingent discoveries. There is a need

Global J. Bus. Soc. Sci. Review 8 (3) 153 - 161 (2020) 
for proficient maintenance and security of intellectual property rights; this is a necessary panacea for stimulating improved monetary output. Hence, intellectual property will continue to contribute to national economic growth if adequate funds, personnel and skills are deployed to ensure adequate security of innovations, creations and inventions in the various sub-sectors.

\section{References}

Adebayo, O., \& Kolawole, J. A. (2013). The historical background of entrepreneurial development in Nigeria: Its gains, shortcomings and needful. Journal of Emerging Trends in Economics and Management Sciences, 4(5), 493. https://search.proquest.com/info/openurldocerror;jsessionid=CF8B20B0273B226422B07B4792CD3512.i-

$0728572 \mathrm{dfa} 9801908$

Adedeji, A. A. (2004). “An Overview of the Nigeria Copyright Law”: Management and industrial Law Journal 3, 2004. https://www.researchgate.net/publication/321365282_Nigeria_Entrepreneurs_and_their_intellectual_properties-

_a_perspective_view

Adewopo, A. (2006). Protection and administration of folklore in Nigeria. https://heinonline.org/HOL/LandingPage?handle=hein.journals/scripted3\&div=3\&id=\&page=

Ahmadu, et al. (2010). Nigerian Law and Practice in a Globalizing World: A Publication of Usmanu Dan Fodiyo University, Sokoto in Honour of the Sultan of Sokoto, Alhaji Muhammed Sa'ad Abubakar, (2010), xiv.

Amparado, M. A. P., \& Miro, A. C. (2020). Intellectual Property: Are Faculty Members Aware of their Rights?. https://doi.org/10.31219/osf.io/wfg9u.

Ayoola, J. B. \& Chikwuendu. D. O. (2014). "An Assessment of Intellectual Property Rights in Nigeria Agriculture" in International Journal of Innovative Research and Development. ISSN 2278 - 0211. http://www.ijird.com/index.php/ijird/article/view/50935/0

Azam, M. (2020). Critical thinking in intellectual property law. International Journal of Law and Management. https://doi.org/10.1108/IJLMA-04-2020-0087

Baten, J., Bianchi, N., \& Moser, P. (2017). Compulsory licensing and innovation-Historical evidence from German patents after WWI. Journal of Development Economics, 126, 231-242. doi:10.1016/j.jdeveco.2017.01.002.

David, I. B. (2007). Intellectual Property (6th Edition) Pearson Education Limited.

Ezekude, A. (2013). The role of the Nigerian Copy Right Commission in the protection and management of Intellectual Property Rights in Nigeria: A paper presented to the WAAPP IPR Sensitization Workshop for the National Agricultural Research Institutes in Nigeria, held at Kakanfo Inn, Ibadan, Oyo State, 2013.

Falvey, R. E., Foster, N., \& Memedovic, O. (2006). The role of intellectual property rights in technology transfer and economic growth: theory and evidence. https://d1wqtxts1 xzle7.cloudfront.net/50390780/The_role_of_intellectual_property_rights20161118-5034-tbtj18.

Federal Government of Nigeria. (2004). The Copyright Act, Cap C28: the Laws of the Federation of Nigeria (LFN), 2004. https://www.lawyard.ng/wp-content/uploads/2015/11/COPYRIGHT-ACT-2004.pdf

Federal Government of Nigeria. (2004). The Patents and Designs Act, Cap P2 the Laws of the Federation of Nigeria (LFN 2004). http://lawsofnigeria.placng.org/laws/P2.pdf

Federal Government of Nigeria. (2004). The Trademarks Act, Cap T13: the Laws of the Federation of Nigeria (LFN) 2004. https://iclg.com/practice-areas/trade-marks-laws-and-regulations/nigeria

International Trademarks Association. (2013). "Policy and Advocacy", available at http://www.inta.org/Advocacy/Pages/main.aspx.

Roisah, K. (2017). Understanding Trade-Related Aspects of Intellectual Property Rights Agreement: From Hard and Soft Law Perspective. Hasanuddin Law Review, 3(3), 277-289. http://dx.doi.org/10.20956/halrev.v3i3.1153

Lemley, M. A. (2015). Property, intellectual property, and free riding. Tex L. Rev., 83, 1031. https://heinonline.org/HOL/LandingPage?handle=hein.journals/tlr83\&div=30\&id=\&page=

Matanmi, S. (2012). "Imperatives of Strategic Capacity Building for Nigeria's Development Futures: Vision 20/2020 as

an Illustration", Nigerian Journal of Labour and Development Studies. 1(2), 39. https://citeseerx.ist.psu.edu/viewdoc/download?doi=10.1.1.872.1106\&rep=rep1\&type=pdf

Obiaya, I. (2013). Taking Nigeria to the movies: The innovative regulatory role of the National Film and Video censors board. Journal of African Media Studies, 5(3), 261-274. https://doi.org/10.1386/jams.5.3.261_1 
Moudio, R. (2013). Nigeria’s film industry: a potential goldmine?. Africa Renewal, 27(1), 24-27.

https://doi.org/10.18356/25582e53-en

Okejiri, E. (2003). National Office for technology acquisition and promotion (NOTAP), speech at Nigeria's imperative in the new World Trade order, workshop report. African economic research consortium (AERC), Nairobi, Kenya and trade policy research and training program (TPRTP). Department of economics, University of Ibadan: Ibadan.

Wessner, C. (2003). Commercialization of academic research results, VINNOVA Verket för Innovationssystem. Swedish Agency for $\quad$ Innovation Systems. https://www.researchgate.net/publication/301261881_Commercialization_of_Academic_Research_Results

Pisacreta, E. A., Ostrow, S. H., \& Adler, K. A. (2011). Intellectual property licensing: forms and analysis. Law Journal Press.

https://books.google.com.pk/books?hl=en\&lr=\&id=OCGsutgMdPIC\&oi=fnd\&pg=PA6\&dq=Raysman, + R., + Edward,+ A.+P.,+\%26+Kenneth,+A.+A.+(2008).+Intellectual+Property+Licensing:+Forms+and+Analysis, + by + Law + Journal + Pr ess,+1998-2008.+ISBN+973-58852-086-

9.\&ots=JUTvXhiISp\&sig=pHy1nmMOYo9_1XBeN6k9mMaAtz0\&redir_esc=y\#v=onepage\&q\&f=false

Rana, F. (2016). "Apple vs. the E.U. Is the Biggest Tax Battle in History?” Accessed: 14 December 2019.

Singla, A. (2008). Valuation of intellectual property, available at: http://bus6900.alliant.wikispaces.net/file/view/article233.pdf, accessed 18 February 2020.

The NationNg. (2013). "Wanted: Intellectual Property Reform”, available at http://thenationonlineng.net/new/law/wanted-intellectual-property-laws-reform/, accessed on 28/05/20.

Umahi, O. T. (2011). Access to Medicines: The Colonial Impacts on Patent Law of Nigeria. Available at SSRN 1975928. http://dx.doi.org/10.2139/ssrn.1975928

Umar A. D \& Muhammad, K. G. (2015). "Legal Regime of Intellectual Property Rights Protection in Nigeria: An Appraisal" published in Journal of Political Science, Law and International Relations. 1(1), 13-26

Umaru, M. J. (2011). Intellectual property law in Nigeria: an introduction. Usmanu Danfodiyo University Printing Press.

Waziri, K. M. (2012). Industrial property rights protection and entrepreneurship development in Nigeria: The economic $\begin{array}{llllll}\text { implication. } & \text { J. } & \text { Pol. } & \& & \text { L., } & 5,\end{array}$ https://heinonline.org/HOL/LandingPage?handle=hein.journals/jpola5\&div=13\&id=\&page=

World Intellectual Property Organization. (2020). WIPO intellectual property handbook: Policy, law and use (Vol. 489). WIPO.

https://books.google.com.pk/books?hl=en\&lr=\&id=r2uADwAAQBAJ\&oi=fnd\&pg=PA1\&dq=World+Intellectual+Pro perty+Organization.+(2004).+WIPO+Intellectual+Property+Handbook:+Policy,+law+and+use,+WIPO+Publication+no .+489+(E),+ISBN+92-805-1291-7,+WIPO+2004,+Second+Edition.+\&ots=-

QJnT1E71C\&sig=GyOaFqVBSivW1y3yeJMo6OrB7Co\&redir_esc=y\#v=onepage\&q\&f=false

Wusu, O. (2013). Legal Protection for Intellectual Property, available at http://www.punchng.com/feature/thelawyou/legal-protection-for-intellectual-property/ Accessed: 15 July, 2020. 